\title{
AN INTRUSIVE-LIKE TECTONIC BRECCIA IN THE ARCHIPELAGO OF SOUTHWESTERN FINLAND
}

\author{
NILS EDELMAN, LEIF BERGMAN and BO LINDBERG
}

\begin{abstract}
EDELMAN, N.; BERGMAN, L. and LINDBERG, B., 1986: An intrusive-like tectonic breccia in the archipelago of southwestern Finland. Bull. Geol. Soc. Finland 58, Part 1, 235-240.

On an islet in the archipelago of southwestern Finland with metamorphic rocks belonging to the Svecofennian zone it is possible to follow in exposure for a distance of some metres the transition from a layered paragneiss with amphibolite bands to a breccia with amphibolitic fragments in a strongly recrystallized gneiss with tonalitic composition. The ultrametamorphic parts of the gneiss lack schistosity. The absence of microcline in these shows that no metasomatic granitization has taken place. The occurrence shows an initial stage of the process which has developed the banded series, a strongly deformed gneiss-amphibolite mixture which forms a zone, about 170 kilometres long, through the archipelago.
\end{abstract}

Key words: tectonic breccia, intrusive-like, paragneiss, recrystallization, Finland.

Nils Edelman, Leif Bergman and Bo Lindberg: Geologisk-mineralogiska institutionen, Abo Akademi, SF-20500 Ảbo, Finland.

\section{Introduction}

During field work for the geological map sheet 1033, Nötö, (Edelman 1956) an instructive case of brecciation was found on the islet of Jämmerskärsgrundet $(\mathrm{x}=6643.60, \mathrm{y}=552.30)$ in the southern part of the commune of Nagu. It has been briefly mentioned in an outline of the geology of the archipelago of southwestern Finland (Edelman 1960). This instance of brecciation is worthy of closer description because on the northern shore of the islet over a distance of a few tens of metres a sedimentary gneiss with amphibolite layers is transformed into a breccia where amphibolite fragments have rotated in a recrystallized gneiss. The recrystallization gives the gneisses a more granite-like appearance and the breccia a more intrusive character. The detailed map was made 1982 with additional sampling 1984.

The islet of Jämmerskärsgrundet is 60 metres long and 40 metres broad (Fig. 1). The bedrock is exposed almost entirely with the exception of some small pools of water as well as of pits and joints in which vegetation has succeeded in establishing a hold. The rocks belong to the Svecofennian zone which was metamorphosed during the Svecokarelian orogeny about 1900-1800 $\mathrm{Ma}$. The supracrustal rocks are mostly older but the intrusive rocks were formed during the orogeny. 


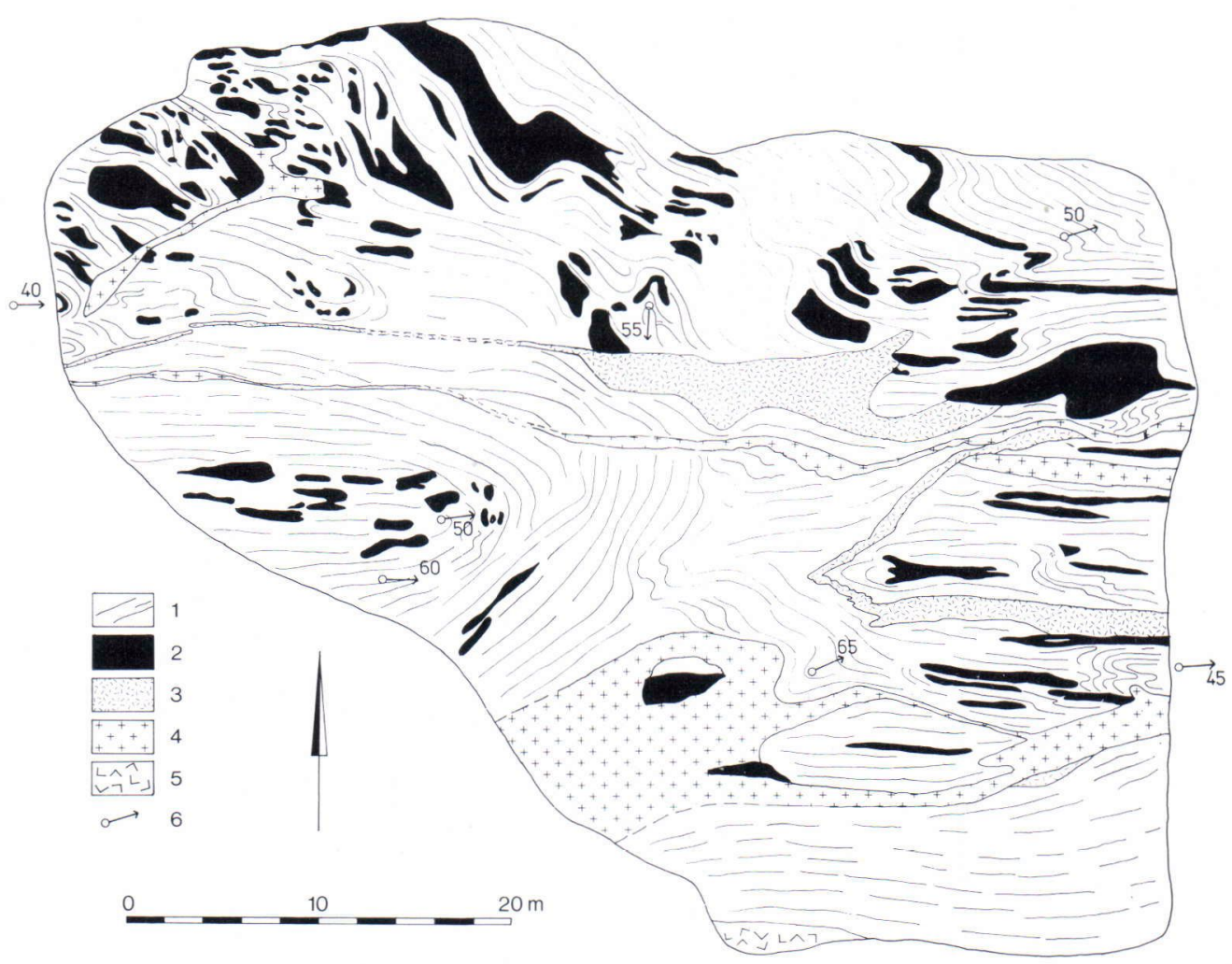

Fig. 1. Geology of the islet of Jämmerskärsgrundet. 1 gneiss, 2 amphibolite, 3 granite, 4 pegmatite, 5 gneissose granodiorite, 6 fold axis.

\section{Description}

The dominating rock is a banded mica gneiss, sometimes garnet-bearing. It is primarily a sediment of greywacke composition containing intercalated layers of amphibolite. Although no volcanic structures are preserved, the amphibolites are evidently of volcanic origin in analogy to other amphibolites in the archipelago.

A gneissose granodiorite together with granitic and pegmatitic dykes are the only intrusive rocks on the islet. The gneissose granodiorite is exposed on the southernmost point. Granite and pegmatite occur as cutting dykes, either rather straight or strongly curved. They show no connection with the breccia.

The northern part of the islet is of primary in- terest because there it is possible to follow the transition from gneisses with amphibolite layers in the east to a breccia with rotated fragments of the amphibolites in a more or less recrystallized, partly palingenetic gneiss in the west. On the northeastern point the gneisses and amphibolites are rather well preserved. In one fold an amphibolite layer has been cut to fragments but it is still easy to follow the layer (Fig. 2). Westwards the amphibolite layers are broken into fragments and only the thickest layer has been strong enough to resist brecciation. Especially on the northwestern point the fragments have rotated in the gneisses (Fig. 3). The gneisses have recrystallized so that the banding has been blurred with the schistosity and it winds around and between the amphibolite fragments (Fig. 3). In many cases 


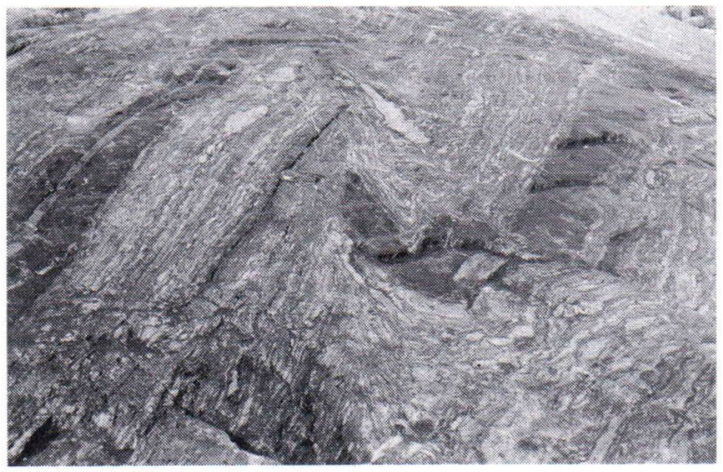

Fig. 2. Fold in the gneisses on the northeastern point. An amphibolite layer has been torn to fragments.

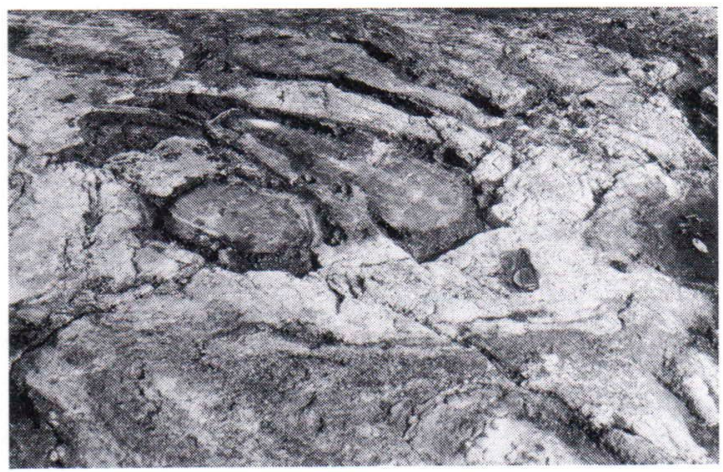

Fig. 3. Breccia with amphibolite fragments in gneiss on the northwestern point. The gneiss shows diffuse banding curving between the fragments. The fragments have dark micarich reaction rims. In many places close to the fragments there is a homogeneous granite-like rock (tonalitic).

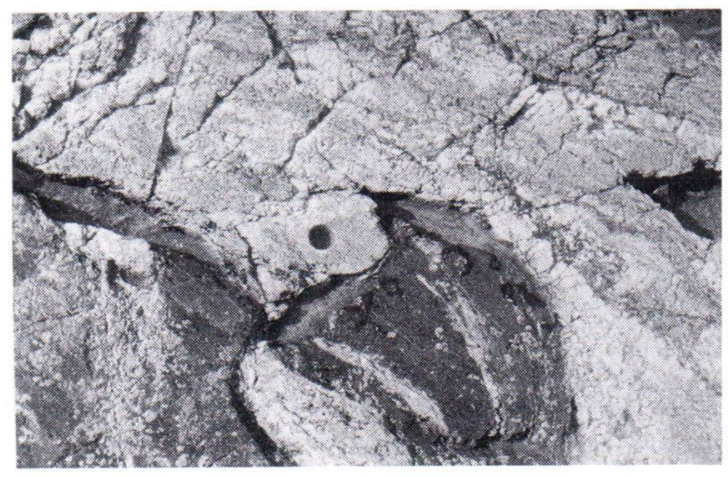

Fig. 4. Detail of the breccia. The gneiss has a diffuse banding. There is a homogeneous granite-like rock (tonalitic) with a drill hole close to an amphibolite fragment. there is a light homogeneous rock without schistosity close to the fragments (Figs. 3 and 4). This rock has a granite-like appearance but is seemingly an ultrametamorphic gneiss. The composition is tonalitic.

\section{Petrographic description}

The gneissose granodiorite is medium-grained. Winding zones of mica and hornblende give the rock schistosity. The main minerals are plagioclase, quartz, biotite and greenish hornblende. The biotite and plagioclase have been rather strongly altered.

The granite consists of quartz, microcline, plagioclase and strongly chloritized biotite. It is granoblastic to porphyroblastic with a weak parallel structure. The plagioclase is strongly sericitized whereas microcline is clear and forms porphyroblasts in part. The pegmatites which are related to the microcline granite have not been studied microscopically.

The gneisses on the eastern shore consist of feldspars, quartz and biotite. Garnet also occurs, even if it is not present in all thin sections. The gneiss changes character from north to south. The rather well preserved layering of the gneiss on the northeastern point becomes more diffuse southwards. The gneiss in the northern part is rich in quartz and plagioclase but comparatively poor in microcline (Fig. 5). Furthermore it contains large spots with sharp limits consisting of aggregates of minute flakes of a light mica-like mineral with moderate birefringence. These seem to be pseudomorphs of cordierite because they sometimes have inclusions of sillimanite needles. The plagioclase and biotite are quite fresh, and the aggregates cannot therefore be alteration products of these minerals. Opaques, apatite and zircon occur as accessories. Some of the zircon grains are rounded.

The gneisses become richer in microcline southwards on the eastern shore. The southernmost gneiss zone in particular is strongly grani- 


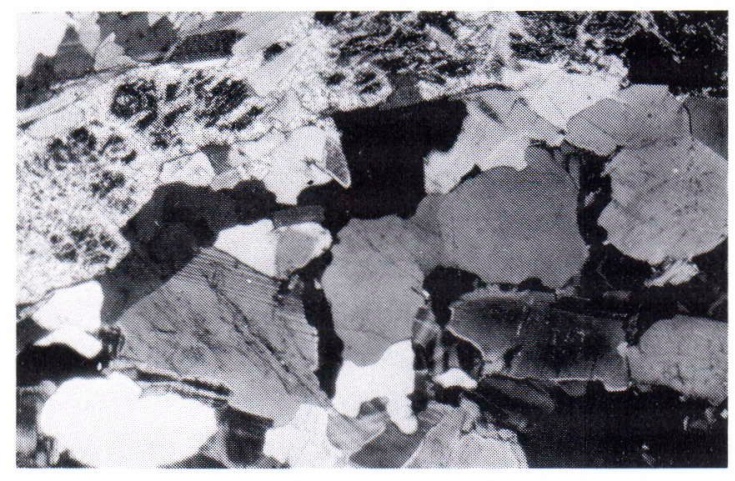

Fig. 5. Photomicrograph. Gneiss from the northeastern point. Quartz, plagioclase, microcline, biotite and aggregate of finegrained mica, probably pseudomorph of cordierite. $40 \mathrm{X},+$ nicols.

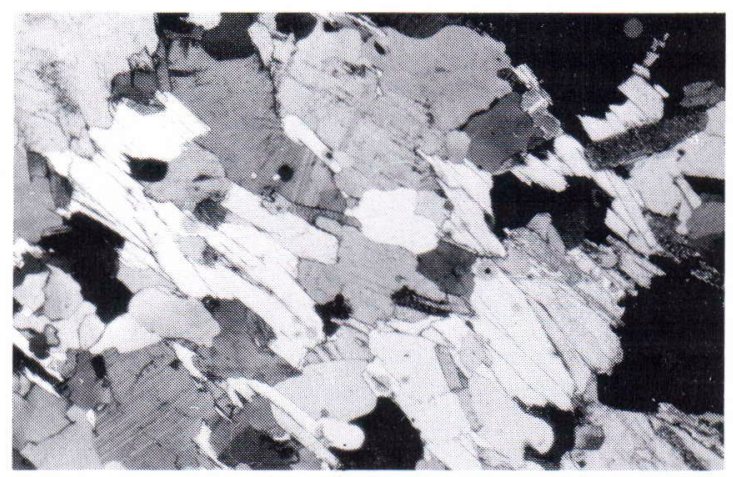

Fig. 6. Photomicrograph. Gneiss from the southwestern part. Plagioclase, quartz, biotite. $40 \mathrm{X}$, + nicols.

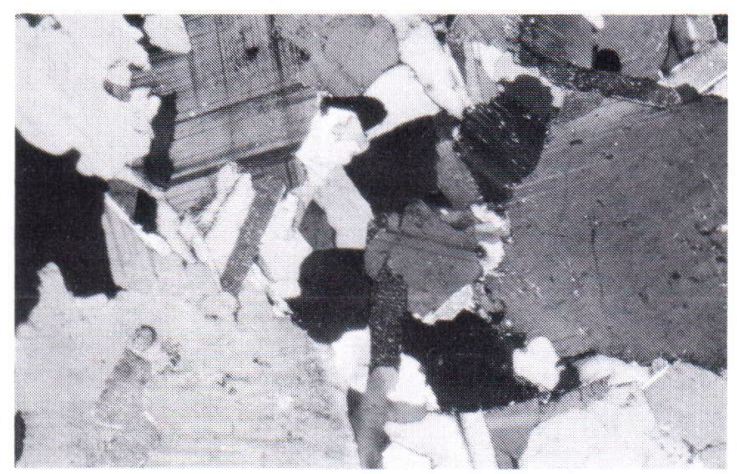

Fig. 7. Photomicrograph. Homogeneous granite-like rock (tonalitic). No signs of schistosity. Plagioclase, quartz, biotite. $40 \mathrm{X},+$ nicols. tized and rich in microcline. Diffuse banding can be seen on the exposures but in microscope scarcely any schistosity can be observed. Microcline occurs as porphyroblasts with inclusions of other minerals.

A gneiss from the middle of the northern shore is medium-grained with slight signs of crenulation and two schistosities. It consists of quartz, plagioclase, biotite and aggregates of small micalike flakes, probably pseudomorphs of cordierite. The biotite is moderately chloritized. Microcline occurs as a few small grains.

The gneisses from the western part of the islet are medium-grained and schistose. They consist of plagioclase, quartz and biotite (Fig. 6). Microcline is absent. Quartz often forms large grains with undulating extinction. Opaques, apatite and zircon occur as accessories. Some zircon grains are rounded.

The homogeneous granite-like rock, which occurs in contact with some amphibolite fragments, is medium-grained and lacks parallel structure. The texture is granoblastic and the mineral composition is quartz, plagioclase and biotite (Fig. 7). Zircon occurs as rather large grains, some of which are rounded, indicating a sedimentary origin, whereas others have crystal shapes but in some cases have a core of a rounded grain.

The amphibolites are medium-grained schistose rocks. In general they consist of hornblende, plagioclase and subordinate quartz. Biotite occurs in most thin sections and the biotite content grows greater southwards. One black layer in the southeastern part was erroneously assumed to be amphibolite in the field; under the microscope it was identified as a gneiss very rich in biotite and poor in quartz and it could hence be a metasomatically transformed amphibolite. One amphibolite on the eastern shore contains not only hornblende but also tremolite. The hornblende is pale greenish and weakly pleochroic. The plagioclase is commonly andesine. In some case it has grown porphyroblastically and contains inclusions of other minerals. Alteration products are sericite, chlorite and epidote. Some amphib- 
olites are, however, free of secondary minerals. Dark reaction rims around some of the amphibolite fragments seem to be rich in dark phyllosilicates, biotite or chlorite, but unfortunately no samples were taken from these.

\section{Discussion}

There is a distinct difference in tectonic style between the eastern and the western parts of the islet. In the east the amphibolites form layers or long lenses in the banded gneisses; in the west the amphibolites are broken fragments which have often rotated in the gneiss. Following the banding over the islet reveals that the gneisses of the western breccia seem to be partly continuations of the gneisses on the middle part of the eastern shore, partly connected with the gneisses of the southwestern shore (Fig. 1). The granite dyke and some pools of water make it difficult to follow the banding in the central part of the islet and this gives rise to some uncertainty in this interpretation. The lack of microcline in the gneisses of the breccia indicates that these are rather continuations of the gneisses of the southwestern shore than of the gneisses of the eastern shore. The difference in microcline content of the gneisses in the east and west cannot, however, affect the competency of the gneisses enough to explain the difference in tectonic style within the islet. We must assume much stronger tectonic movements in the western part to explain the brecciation. We have unfortunately no way of analyzing the causes of the movements because the bedrock is hidden by sea many hundreds of metres in all directions around the islet.

We can establish that the amphibolite fragments in the breccia are broken parts of former layers, the thickest of which has resisted the movements better and has been only folded. Over a distance of only a few metres the tectonic style changes from rather regular banding to a chaotic breccia. The gneisses of the breccia are recrystallized and homogenized so that only indistinct banding is still visible. Ultrametamorphic parts of the gneiss occur around the fragments where the differential movements and the differences in pressure have been greatest. The lack of microcline in the granite-like rock (tonalite) shows that it has not been affected by any kind of metasomatic granitization.

On Jämmerskärsgrundet it is possible to follow the transition in tectonic style from a sedimentary gneiss with amphibolite layers to a breccia where amphibolite fragments have rotated in a strongly metamorphosed gneiss which has partly been recrystallized to a homogeneous rock with tonalitic composition. If this process had continued to its conclusion, this tectonic breccia should have acquired an intrusive appearance with amphibolite fragments floating in stonalite». Rounded zircon grains would possibly still give a hint of the sedimentary origin.

We think that the brecciation on this islet shows the initial stage of the evolution which has produced the banded series forming a 170 kilometre-long zone through the archipelago some kilometres south of this islet (Edelman 1960, Edelman \& Järkkälä 1983). This banded series is characterized by elongated schlieren of amphibolite and angular or eye-shaped ultramafic fragments in recrystallized gneisses. The origin of this series is obscure but it has been interpreted as a melange. The example of brecciation described here throws some light upon the origin of the banded series.

Acknowledgements. Mrs Merja Puumala drew the map and $\mathrm{Mr}$ Cristopher Grapes corrected the language. 


\section{References}

Edelman, Nils, 1956: Suomen geologinen kartta, $1: 100$ 000, lehti - sheet 1033, Nötö. Kallioperäkartan selitys. Summary: Geological map of Finland. Explanation to the map of rocks. $44 \mathrm{p}$.
—, 1960: The Gullkrona Region. Bull. Comm. geol. Finlande $187,87 \mathrm{p}$.

— \& Jaanus-Järkkälä, Mirja, 1983: A plate tectonic interpretation of the Precambrian of the Archipelago of south-western Finland. Geol. Surv. Finland, Bull. 325. $33 \mathrm{p}$. 